\title{
System Analysis Of Domestic Wastewater For The Settlements In North Surabaya
}

\author{
Farid Afriandi Nugraha ${ }^{1, F}$. Roosslan Edy Santosa ${ }^{2}$ \\ Narotama University \\ faridafriandin@gmail.com
}

\begin{abstract}
Domestic wastewater is dirty water result from community waste. According to the society, waste is just plain dirt harmless. because of a little knowledge about their impacts. The research method used qualitative descriptive analysis. The data obtained through interviews and observations in the field. The analysis concluded that the limited public knowledge about domestic waste. Society tends to dispose of wastewater former kitchen, laundry, etc. in the area drains, rivers and streams that exist around them, different wastes fecal waste they dispose of. Throw it in the cesspool of society that has been available in each home. The results showed a wastewater treatment system in the area of North Surabaya using the system on-site. This system uses a network of sludge container which is in the same location as the canal closets. Education needs to be done to build a network of off-site to accommodate domestic waste from the community.
\end{abstract}

Keywords: Domestic Wastewater, on-site management system, North Surabaya.

\begin{tabular}{|c|c|c|}
\hline Received & Revised & Published \\
\hline 11 January 2019 & 17 February 2019 & 30 March 2019 \\
\hline
\end{tabular}

\section{INTRODUCTION}

Sustainable Development Goals(SDGs) is aimed at sustainable development for the benefit of humans and the planet. This agenda has been run as a UN resolution on October 21, 2015 and 2030, has the ambition to build together. These SDGs in lieu of the Millennium Development Goals that began in 2000 to 2015. SDGs signed by 189 world leaders as the millennium declaration.

Environmental Health Risk Assessment Study (EHRA) or Health Risk Assessment Study. EHRA study aims to provide scientific data and factual about the availability of sanitation at the household level Regency / City. EHRA will take a sample by conducting a live interview questionnaire respondents in several District in the city of Surabaya, which is directed by five (5) Pillars of Community-Led Total Sanitation (STBM) developed by the ministry of RI. Sanitation component is the object of study EHRA is domestic sewage, solid waste / environmental waste 


\section{THE SPIRIT OF SOCIETY JOURNAL}

International Joumal of Society Development and Engagement

ISSN : 2597-4777 (Online) - ISSN : 2597-4742 (Print)

This work is licensed under a Creative Commons Attrib ution-ShareAlike 4.0 International License.

and drainage, as well as the Hygiene and Sanitation Behavior including Handwashing Practices (CTPS) (Christine Sijbesma, 2014).

Waste is the result of the waste impurities occur in an industrial environment, domestic (household), and hospitals. According to Metcalf and Eddy (1972), limit wastewater expressed as a combination of fluid and the waste liquid coming from residential areas, commercial, office and industrial.

Domestic waste water is dirt in the form of garbage generated from the production community. Domestic wastewater pollution makes a very big threat, as the water becomes cloudy and there are a lot of harmful bacteria that live in polluted area domestic waste. Domestic waste is often encountered in densely populated areas, slums and a flowing river. In general, the traits associated slum area on the physical condition of the environment, the definition of slums are region formation process due to limitations in the city use of urban land. While the high density residential area of the embryo slums. In addition, the slum is an area geographically spread locations pressed for development of the city which was originally good, slowly becoming rundown. The cause is the social mobility of the stagnant economy (Silas in Sartono and Joni Hermana, 2009). Related to this study, the research titled Analysis of Domestic Waste Water System in North Surabaya On the Settlement will be done with the hope of researchers informed and get as much detail as factual and valid data.

\section{RESEARCH SITES}

This study will be conducted in the area of North Surabaya. The location of this research focuses on the problems faced by the domestic waste in North Surabaya which has a red zone. This research was conducted in the district Krembangan (Morokrembangan Village, Village South Krembangan, Village Kemayoran, Village Dupak and Silver Village West) and sub-Bulak (Bulak village, Village Kedungcowek, Village and Village Kenjeran New Sukolilo) as the sample will get.

\section{METHOD}

The collection of data was taken from the observation process the data from the primary data, namely:

\section{Interview}

The interview is the process of obtaining data from the respondents naturally, accurately and there is no pressure or interference from any outside party. Data taken in EHRA rules that are constructed in the form of a questionnaire. The interview is a meeting of two people to exchange information and ideas through questions and answers that can be constructed meaning in a particular topic and to interviews, researchers will know the things that are more in-depth about the participants in interpreting situations and phenomena that can not be found through observation (Sugiono, 2009: 317) 


\section{THE SPIRIT OF SOCIETY JOURNAL}

International Joumal of Society Development and Engagement

ISSN : 2597-4777 (Online) - ISSN : 2597-4742 (Print)

This work is licensed under a Creative Commons Attrib ution-ShareAlike 4.0 International License.

\section{Observation}

Observation data collection is done by watching how a factual circumstances at the location or the home of respondents who were interviewed. According Supardi (2006: 88), "An observation method is a method of data collection is done by observing and recording systematically investigated symptoms.

Determination of the number of samples obtained from the calculation equation Slovin:

$n \frac{N}{1+N e^{2}}$

North Surabaya has a total of 67.164 inhabitants (Surabaya in Figures, 2017). The calculation of a total of 398 respondents get results with a degree of confidence of $95 \%$, the percentage of errors have a level of $5 \%$, so the margin of error is $5 \%$.

\section{RESULTS AND DISCUSSION}

The result of this calculation analysis of 400 samples obtained a number of interviews and observations in the field, so that the results obtained are valid and factual.

The following figure describes the status of each respondent house located in North Surabaya with the status of home ownership vary depending on the location of the study. The home status has relationships with existing activities in the home environment, ranging from defecation (BAB), dispose of kitchen waste, etc.

Here are the total and the percentage of home ownership status:

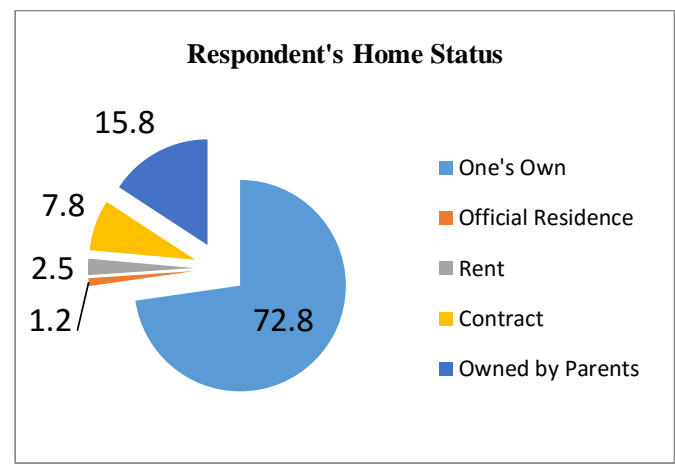

\section{Figure 2. Graph Status Home Based Sub-District}

A total of 397 respondents said that adults use a private latrine for defecation activities and while three respondents said they use the toilet / WC is common for them to defecate, in Figure 3 shows the total respondents who use private latrines and other : 


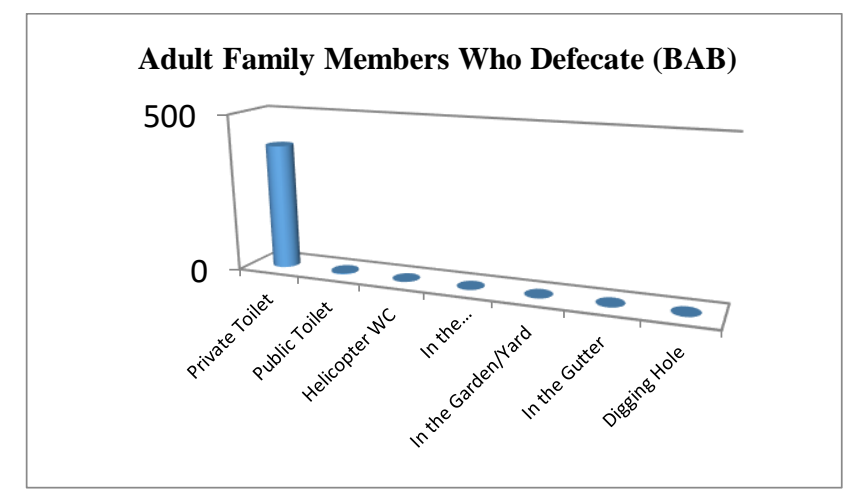

Figure 3. Chart Family Members of Adults defecation (BAB)

Figure chart above has a total of 397 respondents who have an individual septic tank as a means of waste fecal or bowel movements, remaining 3 respondents chose public toilet to dispose of their faeces.

There are several types of toilets that we managed to meet for interviews Figure 4 shows the number of users existing toilet:

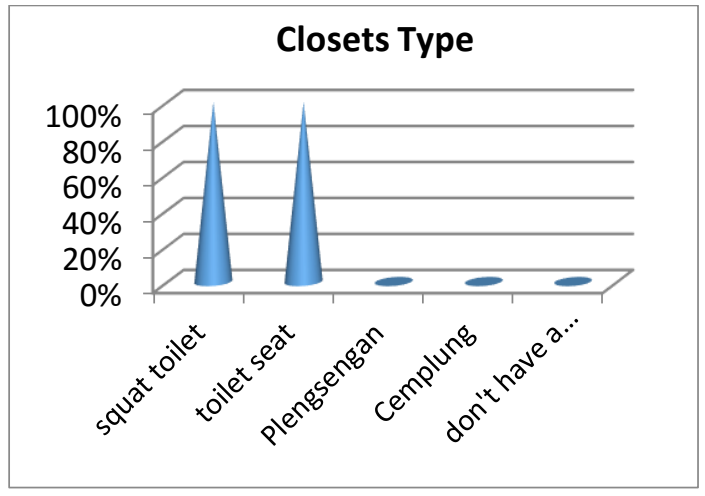

Figure 4. Graph the total species present in the environment Toilet respondents

In the graph Figure 4 shows a total of 281 respondents had squat toilets as their means to dump the sludge, and a total of 119 respondents had a toilet seat for defecation them

Places dealer or landfill feces in North Surabaya most have a method where the same waste container, ie septic tank, or so-called on-site systems with the condition that has a location at the bottom of the canal adjacent to the toilet or lavatory. The following Figure 5 is a data set where the dealer sludge. 


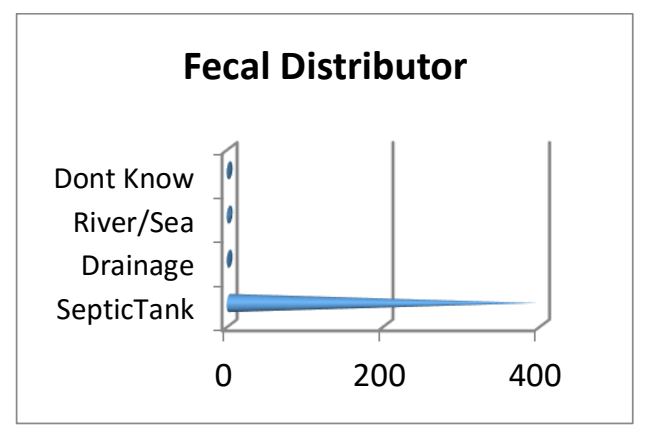

Figure 5. Graph Final Distribution Points Feces

Figure 5 shows a total of 395 of the 400 respondents use septic tanks to collect the proceeds of their fecal waste, while the rest chose to throw into the river, lake or coastal drainage and the rest did not know the fecal waste. Cesspool become the most common means and still rational for this current waste container.

Data taken from a total of 400 respondents were obtained, most respondents own more than 10 years had a septic tank as their fecal waste container, then the respondent has had a septic tank in the range of 5th year until the 10th year. Figure 6 shows the old data saptik tank built:

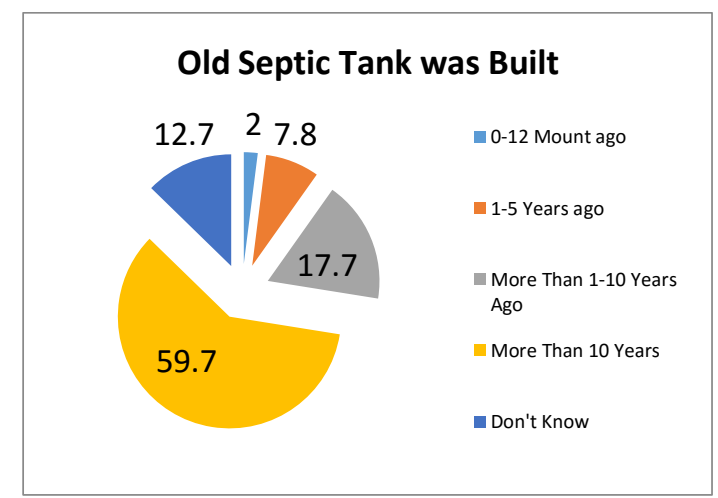

Figure 6. Percentage Graph Lama in the Septic Tank Build on the House Respondents

Figure 6 shows a total of $59.7 \%$ of respondents already have septic tanks for more than 10 years as their fecal waste container. The above data indicate that the respondent had had the thought to treat waste exhaust their feces to make the building a septic tank, which at times can be full and it will do the transport as shown in Figure 7, which has the data as a means of canal or carrier services to do the processing and disposal.

Data from the septic tank built will determine how many times the respondent drain the septic tank. The longer the septic tank was built, the more often the septic tank to be refilled carried dewatering of sludge. Here in Figure 7. There are details of dewatering is done based on interviews of respondents. 


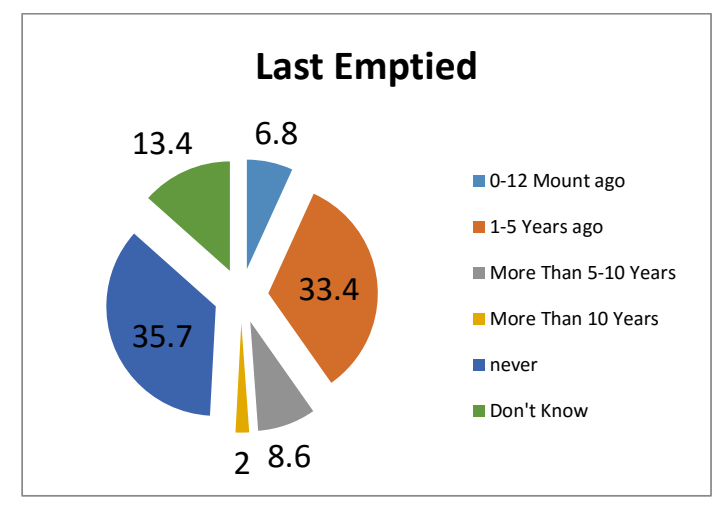

Figure 7. Graph Recently Septic Tank on Empty

Pictures of the pie charts above have a total of $35.7 \%$ of respondents give information about the last time they deplete their septic tank. As many as $141(35.7 \%)$ of respondents to provide information 'never' and the second one was recorded at $132(33.4 \%)$ answered dewatering is done in 1-5 years ago.

Here are the data taken to determine what kinds of emptying services performed to empty the contents of the tank:

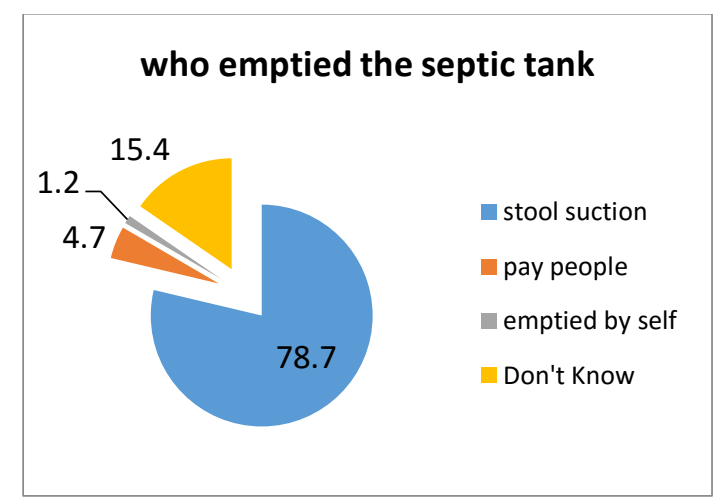

Figure 8. Graph Discharging Septic Tank

A total of 141 respondents did not know, then the remaining 259 know who is using the service to empty the septic tank. A total of $78.7 \%$ of respondents use lipo services feces as service providers and the rest use other services, not even knowing about the problem of emptying the septic tank. 


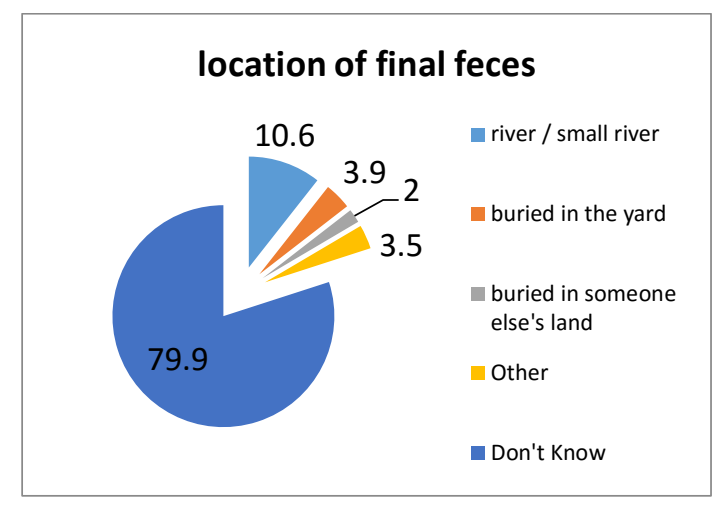

Figure 9. Percentage Area Graph Wasters End Feces

Total 400 menyatan that most of them do not know about the location of final disposal of feces, a total of $79.9 \%$ said that they did not know where the results of liposuction fickle disposal or where, but a total of $10.6 \%$ said that the fecal waste to dispose of river. The remaining states are buried in the yard, buried in the land of others and others.

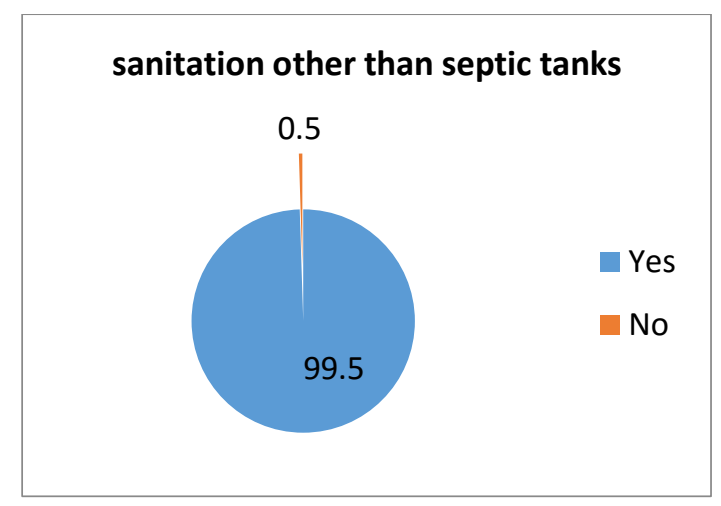

Figure 10. Percentage of Waste Processing Graph addition Feces

A total of 398 of the 400 respondents had a waste water processing besides the processing feces. The remaining 2 respondents did not have a place other than the sludge processing.

Here are the locations of wastewater treatment performed in addition to sludge. Waste kitchen, laundry, bathroom and wastafel. In Figure 11. will show the total presesntase chart on the kitchen waste disposal to be done based on the results of the questionnaire: 


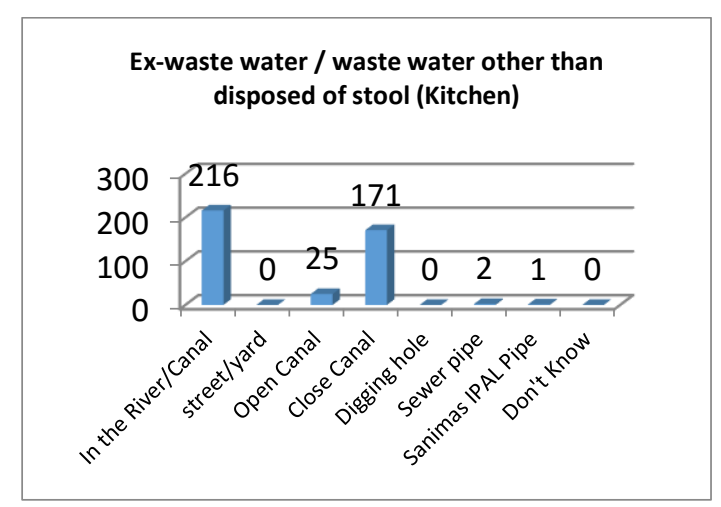

Figure 11. Graph Waste Disposal Kitchen Results

Figure 11 shows the total graph that answer most kitchen waste disposal into the river as much as 216 respondents. The rest chose to throw away their kitchen waste into a closed canal as much as 171 respondents and open canal has a total of 398 respondents 25 .

Figure 12. shows the location of the former sewerage washing clothes.

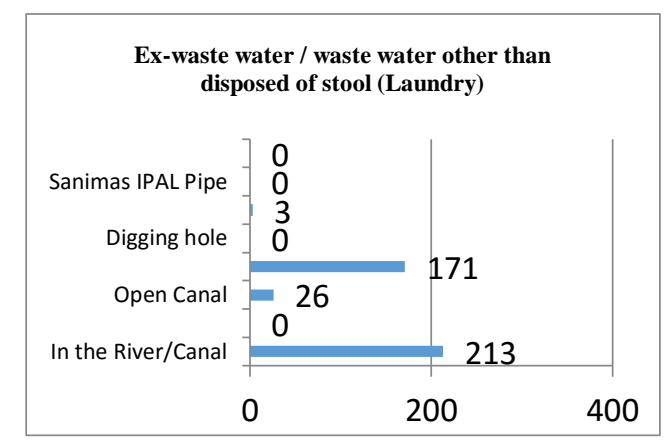

Figure 12. Graph Distributors Laundry Waste Water Used

Figure 12. shows a graph highest total answer sewage into the river washing clothes as much as 213 respondents. The rest chose to dispose of residual waste to drain wash their clothes covered as much as 171 respondents and open canal has a total of 398 respondents 26 . 


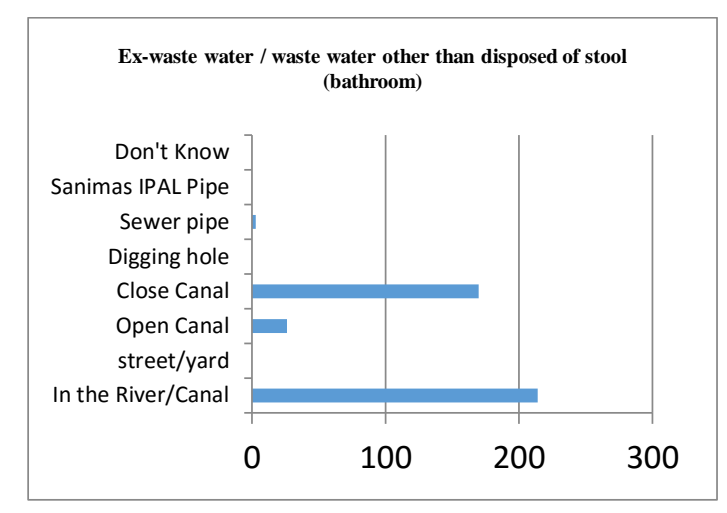

Figure 13. Graph Former Waste Water Distributors Bathroom

Figure 13. shows that the highest total chart answered bathroom waste into the river as much as 214 respondents. The rest chose to throw away their kitchen waste into a closed canal 170 respondents and open canal has a total of 398 respondents 26.

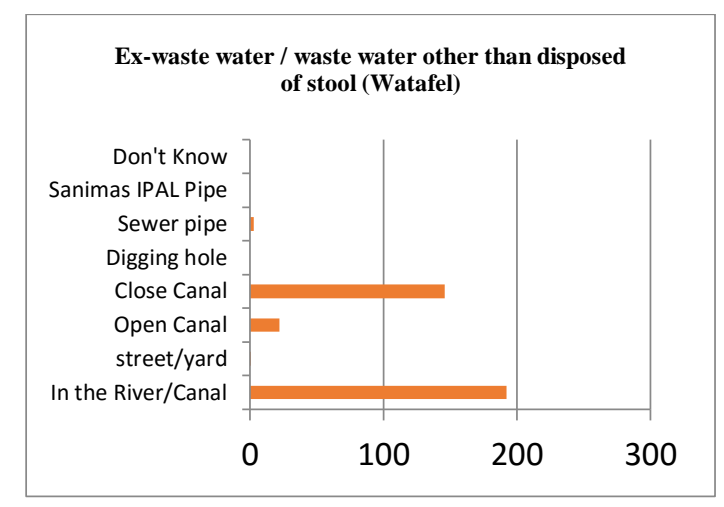

Figure 14. Graph Distributors Used Waste Water Sink

Figure 14. shows a graph highest total answer kitchen waste into the river as much as 192 respondents. The rest chose to throw away their kitchen waste into a closed canal as much as 146 respondents and open canal has a total of 398 respondents 22 . 


\section{CONCLUSION}

Discussion and analysis of the results obtained in the questionnaire EHRA, then it can be concluded as follows:

1. Waste water treatment system in the area of North Surabaya is almost total $100 \%$ of respondents said water treatment system of domestic waste in the form of sludge using the system on-site, where the system is a system of inter-individual owner of the house and in use for the container whilst sludge proceeds exhaust respondents and almost total $100 \%$ of respondents use public facilities such as drains, canal and rivers for disposing of waste in the form of kitchen waste, sewage laundry, bathroom and other waste.

2. The process of using waste water system in the community is that people use latrines or toilets to dispose of feces and then the sludge into the system on-site or trapping systems fecal waste using a septic tank, and sludge are in the drain by using the services of suction feces and do penggolahan sludge the area of waste treatment in the city of Surabaya, other wastewater such as sewage kitchen, bathroom, sink and other domestic wastes, the people using the area drains, canal and rivers to dispose of them without having to go through the shelter to be processed prior to disposal.

\section{REFERENCES}

Badan Pusat Statistik. (2017). Surabaya Dalam Angka. Surabaya: Badan Pusat Statistik Kota Surabaya.

Metcalf dan Eddy. (1972). Wastewater Engineering: Collection Treatment Disposal. HIm. 283. New York: McGraw-Hill.

Sartono dan Joni Hermana. Strategi Pengelolaan Air Limbah Domestik Pemukiman Kumuh Kota Palembang. ISBN 978-979-18342-1-6. Surabaya: Institut Teknologi Sepuluh November.

Sijbesma, Christine. (2014). Panduan Praktis Pelaksanaan EHRA (Environmental Health Risk Assessment / Penilaian Risiko Kesehatan Karena Lingkungan). Jakarta.

Sijbesma, Christine.dkk.(2014). Panduan Praktis Pelaksanaan EHRA (Environmental Health Risk).Jakarta: USDP

Silas, J, (1996), Kampung Surabaya Menuju Metropolitan, Permukiman Marjinal Amat Liat.

Sugiono. (2009). Metode Penelitian Pendekatan Kuantitatif, Kualitatif dan R \& D. Bandung: Alfa Beta.

Supardi, M.d, (2006). Metodologi Penelitian. Mataram : Yayasan Cerdas Press. 